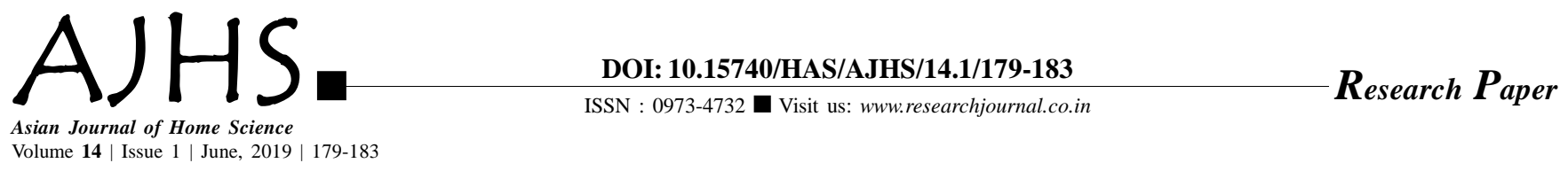

\title{
Empowerment of deceased farm families through income generating activities
}

\author{
Bhavini B. Patil and Suma M. Hasalkar
}

See end of the paper for authors' affiliations Bhavini B. Patil

Department of Family Resource Management, College of

Community Science, University

of Agricultural Sciences, Dharwad

(Karnataka) India

Email : barbiebhavini@

gmail.com

Received: 15.10.2018; Revised: 08.05.2019; Accepted: 17.05.2019

ABSTRACT : The sudden, unexpected death of a close person often shocks his family, friends and other known people. With suicide, the problem, pain, suffering and trauma is merely transferred to those who survive and is experienced by everyone in the family. After the suicide of the family head, the income of the family will be lowered and the whole responsibility of the family lies on women. Training of women in deceased farm families is important to increase their income, enhance their skill and to make the women self sufficient to meet out the needs of the family. The present study was conducted to estimate training need of the deceased families in different income generating activities. A total of 50 respondents were selected purposively in five taluks of Dharwad district. Data were collected by using the checklist developed by AICRP2007 on income generating activities as well as self structured interview schedule. The results notify that 64 per cent of the respondents were interested to take training on income generating activities. Among those 60 per cent of the respondents were interested to take training on preparation of soaps and detergents followed by preparation of candle $(56.00 \%)$. Based on needs of the respondents the trainings were given to 30 respondents on preparation of soaps and detergents, preparation of phenyl and scouring powder, preparation of agarbatti and candles. Majority of the respondents have gained knowledge from the training on income generating activities which was highly significant.

KEY WORDS: Deceased family, Training, Income generating activities

- HOW TO CITE THIS PAPER : Patil, Bhavini B. and Hasalkar, Suma M. (2019). Empowerment of deceased farm families through income generating activities. Asian J. Home Sci., 14 (1) : 179-183, DOI: 10.15740/HAS/AJHS/14.1/179-183. Copyright@ 2019: Hind Agri-Horticultural Society. 